\title{
Emergence of the invasive malaria vector Anopheles stephensi in Khartoum State, Central Sudan
}

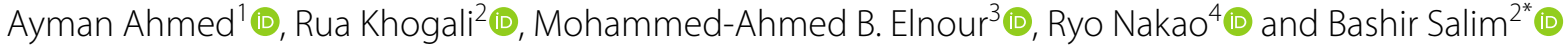

\begin{abstract}
The emergence of the Asian invasive malaria vector, Anopheles stephensi, has been identified in Khartoum, the capital city of Sudan. This is the first report that confirms the geographical expansion of this urban mosquito into Central Sudan. We urgently recommend the launch of a national entomological survey to determine the distribution of this invasive disease vector and to generate essential information about its bionomics and susceptibility to available malaria control measures.
\end{abstract}

Keywords: Anopheles stephensi, Emergence, Invasive diseases vector, Asian malaria vector, Malaria, Sudan

Anopheles stephensi is an invasive disease vector that is originally endemic in Asia and competent in transmitting both malaria parasites Plasmodium falciparum and P. vivax [1]. Anopheles stephensi has recently invaded Africa, specifically the Horn of Africa [2]. It was first reported in Djibouti (2012) and Ethiopia (2016) [3, 4]. Furthermore, in 2019, this mosquito species was detected in the coastal and sub-coastal regions of the Red Sea in Sudan [5]. Considering the heavy burden and high risk of malaria in Africa, with more than $94 \%$ of the 229 million globally estimated cases in 2019 being reported from Africa, the majority of cases were in individuals living in the sub-Saharan region, which includes Sudan [6]. The establishment of this competent malaria vector in Africa is of global importance. The World Health Organization (WHO) has raised an alarm about the invasion and spread of An. stephensi into Africa to urge national malaria control programmes and their partners in areas at risk to be vigilant and to improve and upscale their

*Correspondence: bashirsalim@gmail.com

2 Department of Parasitology, Faculty of Veterinary Medicine, University of Khartoum, P.O. Box 32, Khartoum North, Sudan

Full list of author information is available at the end of the article surveillance systems for the early detection and control of this invasive mosquito species [5].

During a fieldwork assignment that focused on collecting Culex and Aedes mosquitoes from Tuti Island $\left(15.6202^{\circ} \mathrm{N}, 32.5062^{\circ} \mathrm{E}\right.$; Khartoum, capital city of Sudan) between August and September 2018 (Fig. 1), 21 unknown Anopheles mosquitoes were aspirated. These were identified to species level using standard morphological keys [7].

Of the mosquitoes collected from Tuti Island, the majority (19; 91\%) of the samples were identified as $A n$. arabiensis, the major malaria mosquito vector in Sudan [8]. However, the remaining two samples (9\%) were morphologically identified as An. stephensi. Considering that An. stephensi has never been reported before in Sudan except for the Red Sea and Gedaref states in 2019, further confirmatory steps were essential. We extracted the total DNA from all 21 Anopheles mosquito samples using DNAzol (Molecular Research Center, Inc., Cincinnati, $\mathrm{OH}$, USA) according to the manufacturer's guidelines. Our genetic analysis confirmed the morphological identification of the mosquitoes by sequencing the cytochrome c oxidase I $(C O I)$ gene $[9,10]$. Phylogenetic analysis original author(s) and the source, provide a link to the Creative Commons licence, and indicate if changes were made. The images or other third party material in this article are included in the article's Creative Commons licence, unless indicated otherwise in a credit line to the material. If material is not included in the article's Creative Commons licence and your intended use is not permitted by statutory regulation or exceeds the permitted use, you will need to obtain permission directly from the copyright holder. To view a copy of this licence, visit http://creativecommons.org/licenses/by/4.0/. The Creative Commons Public Domain Dedication waiver (http://creativeco mmons.org/publicdomain/zero/1.0/) applies to the data made available in this article, unless otherwise stated in a credit line to the data. 


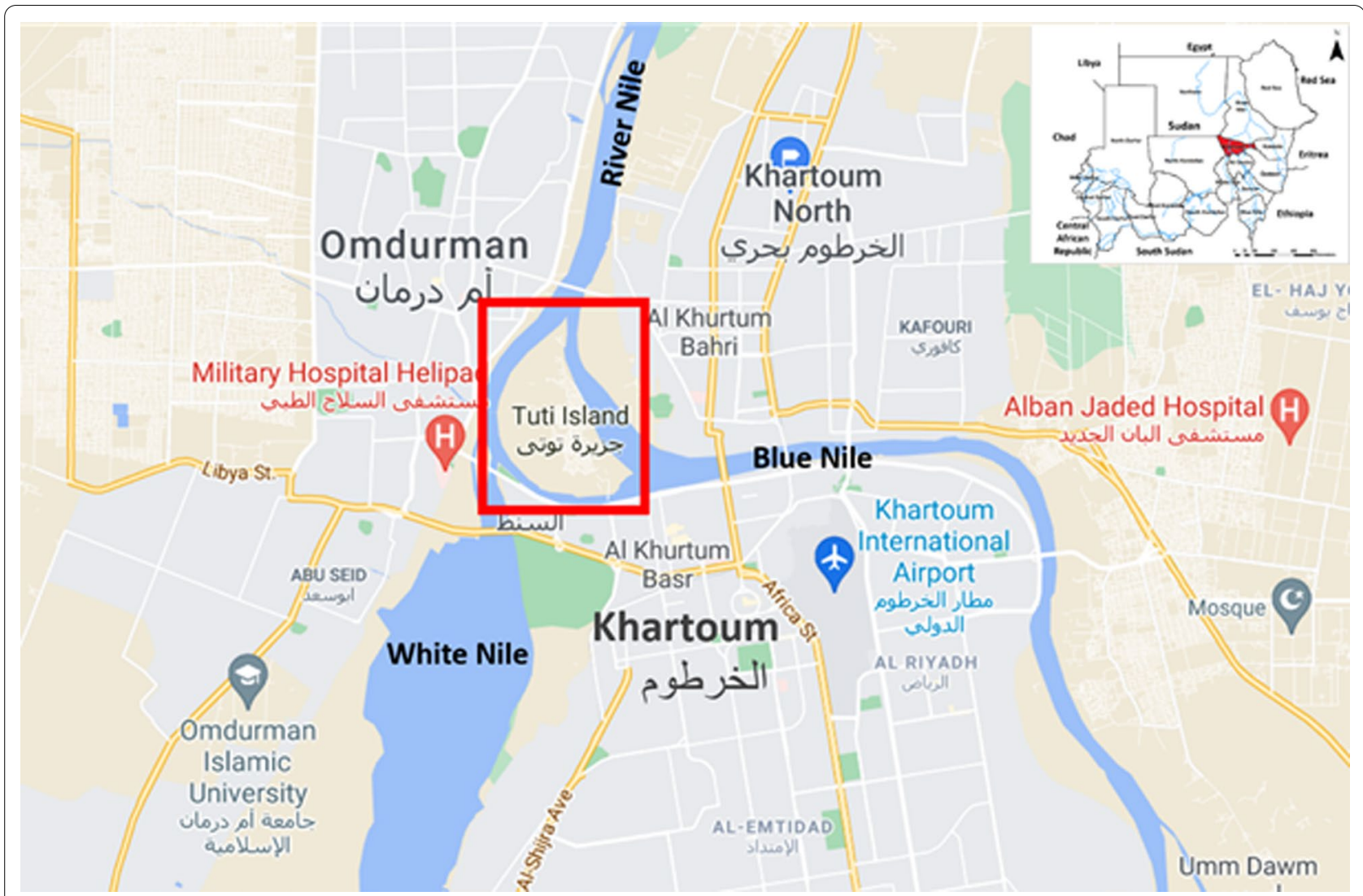

Fig. 1 Inset map shows the location of the Anopheles mosquito samples collected (red square)

suggests that An. stephensi from Sudan is closely related to the An. stephensi from Ethiopia (Fig. 2).

This is the first report of An. stephensi in Khartoum State, Central Sudan. Our serendipitous finding suggests this mosquito species has spread beyond the coastal regions and into Sudan's interior, thus highlighting the pressing need to conduct a countrywide survey. Such a survey would help establish an accurate distribution map for this disease vector and would provide data to predict further species invasion into the five neighbouring $A n$. stephensi-free countries: the Central African Republic, Chad, Egypt, Libya, and South Sudan. Recently developed prediction models based on current An. stephensi distribution patterns and habitat suitability have indicated high potential risk for the spread of An. stephensi unless very strict control measures are rapidly adopted alongside targeted entomological surveillance [2]. Previous studies warned of the serious threat of unprecedented epidemics of malaria in large cities in Africa, including Khartoum, if they were invaded by An. stephensi [11], particularly because the national vector surveillance systems in Africa are experienced and oriented toward the rural endemic vectors, not the urban An. stephensi [11].
The invasion of An. stephensi populations into the Republic of Djibouti in 2012 was associated with several urban malaria epidemics. The disease was controlled by combination of larvicides, thermal fogging of insecticides, and habitat sanitation $[3,12]$; other studies warn that similar scenarios might develop throughout Africa if this vector continues to spread into other densely populated urban areas [11]. It is unknown yet whether the recent (2018 and 2019) malaria epidemic in South Kordofan, Sudan, is linked to the establishment of a new An. stephensi population in the area [13]. The serious threat of malaria epidemics in Africa due to the spread of An. stephensi in the area prompted WHO to issue a vector alert in 2019 [5]. This alert was raised to encourage the African countries that already had established populations of An. stephensi, or that shared borders with countries reporting the presence of this vector, to update their strategies and guidelines for mosquito surveillance and control [5]. Furthermore, WHO aimed to mobilize local and international resources to improve their national vector surveillance system and to increase the capacity of their surveillance and control teams in order to implement surveys 


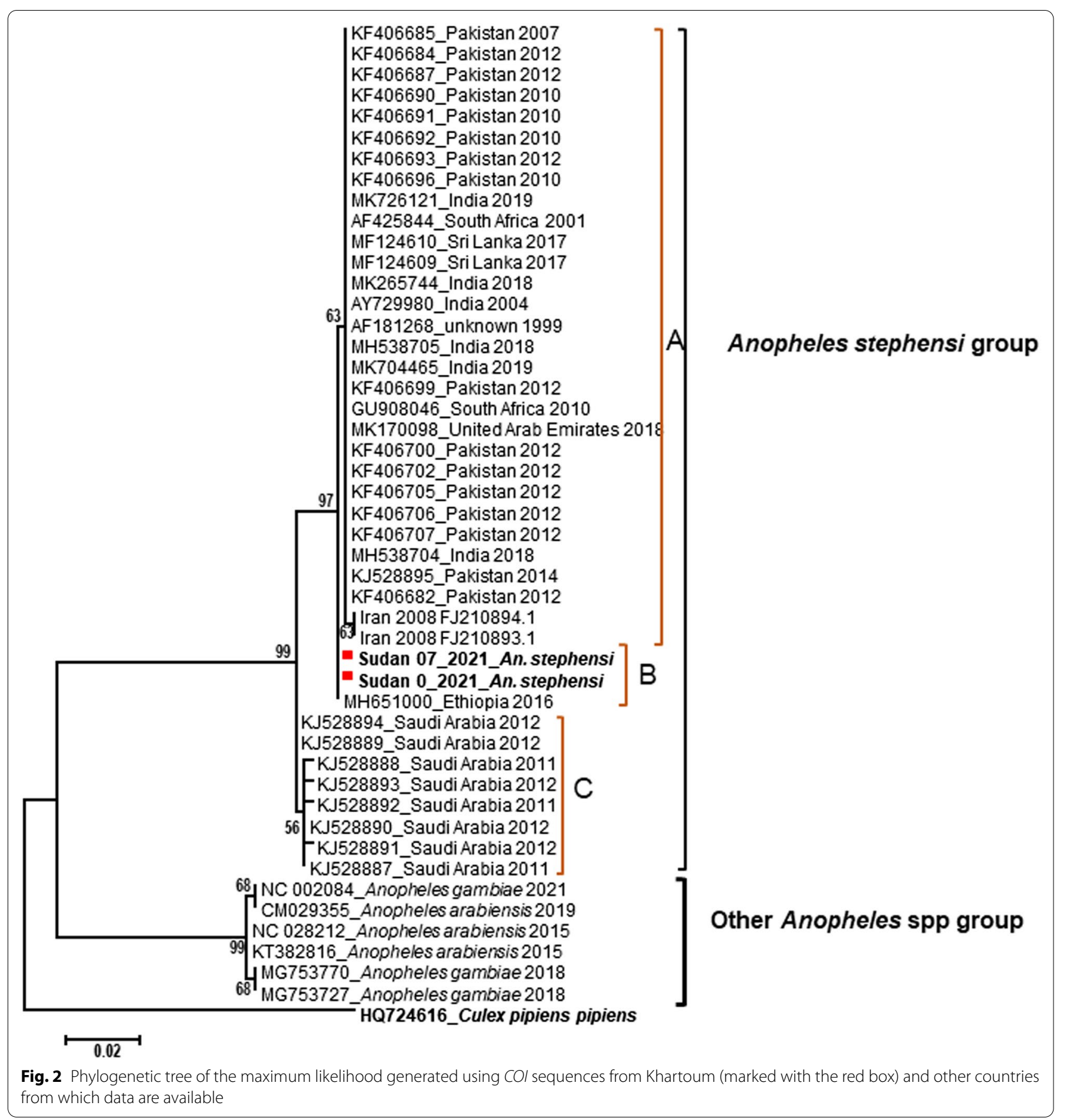

for the early detection and reporting of An. stephensi. It is important to gather data and fill current information gaps on An. stephensi bionomics in Africa, including the feeding and resting behaviours and preferences. Determining how susceptible these populations are to the locally implemented vector control measures is also important in order to deliver a timely and effective response that averts the local establishment and further spread of An. stephensi [5]. Considering the zoophilic nature of An. stephensi, it might be useful to adopt innovative and environmentally friendly vector control tools such as endectocides including nitisinone and ivermectin for the control of this species [14, 15]. Strict implementation of the International Health Regulations (IHR 2005) is essential to prevent this mosquito from invading other An. stephensi-free countries [5]. 
Further studies are needed to investigate the risk factors in Sudan that influence the spread of An. stephensi and also to target the possible invasion routes to improve disease prevention and control interventions [16]. Surveillance systems in the countries with confirmed presence and/or high risk of An. stephensi emergence could use satellites to produce evidence-based habitat suitability prediction models for early detection [2]. More importantly, molecular and genetics-based tools should be incorporated into the national vector surveillance systems to establish an early warning/ response system that would quickly detect the introduction of invasive disease vectors before they adapt and establish locally $[3,4,17]$.

In conclusion, in this report we document the first detection of the invasive Asian malaria-transmitting vector An. stephensi into Khartoum State, Central Sudan. The arrival of this mosquito is of high public health concern due to the threat of urban malaria outbreaks in the densely populated state of Khartoum. We strongly emphasize the need to deploy a national vector survey that targets An. stephensi in order to (1) determine the geographical distribution of this disease vector across the country, (2) provide evidence on feeding and resting behaviours in relation to its susceptibility to current vector control measures, and (3) identify how An. stephensi contributes to local malaria transmission. Such a survey should be informed by habitat suitability prediction models and supported with genomic tools. We urge the Sudan Ministry of Health, malaria stakeholders, and their partners to mobilize resources and implement a strategic prevention and control action plan to prevent the local establishment and/or further spread of this invasive vector in the country and the region. Several measures need to be in place for the success of such an action plan, including upscaling the surveillance system and implementing intensive surveys, deploying effective vector control interventions, and strictly implementing the International Health Regulations.

\section{Authors' contributions}

AA and BS conceptualized and designed the study and analysed the data. RK, $M A B A, R N$, and BS led the investigation and data collection. AA and BS wrote, revised, and edited the manuscript. All authors read and approved the final manuscript.

\section{Funding}

Funding was provided by the Japan Society for the Promotion of Science (Grant Nos. 15H05633, 16H06431 and 19H03118).

\section{Availability of data and materials}

The datasets supporting the conclusions of this article are included within the article. Our An. stephensi DNA sequences were submitted to GenBank under the following accession numbers: SUB10169984 01 Anopheles MZ725449 SUB10169984 02_Anopheles MZ725450

\section{Declarations}

Ethics approval and consent to participate Not applicable.

\section{Consent for publication}

Not applicable.

\section{Competing interests}

The authors declare that they have no competing interests.

\section{Author details}

${ }^{1}$ Institute of Endemic Diseases, University of Khartoum, 11111 Khartoum, Sudan. ${ }^{2}$ Department of Parasitology, Faculty of Veterinary Medicine, University of Khartoum, P.O. Box 32, Khartoum North, Sudan. ${ }^{3}$ Department of Parasitology \& Medical Entomology, Tropical Medicine Research Institute, National Center for Research, P.O. Box 1304, 11111 Khartoum, Sudan. ${ }^{4}$ Laboratory of Parasitology, Faculty of Veterinary Medicine, Graduate School of Infectious Diseases, Hokkaido University, Sapporo, Japan.

Received: 10 August 2021 Accepted: 16 September 2021

Published online: 02 October 2021

\section{References}

1. Tadesse FG, Ashine T, Teka H, Esayas E, Messenger LA, Chali W, et al. Anopheles stephensi mosquitoes as vectors of Plasmodium vivax and falciparum, Horn of Africa, 2019. Emerg Infect Dis. 2021;27:603-7.

2. Sinka ME, Pironon S, Massey NC, Longbottom J, Hemingway J, Moyes $\mathrm{CL}$, et al. A new malaria vector in Africa: predicting the expansion range of Anopheles stephensi and identifying the urban populations at risk. Proc Natl Acad Sci USA. 2020;117:24900-8.

3. Faulde MK, Rueda LM, Khaireh BA. First record of the Asian malaria vector Anopheles stephensi and its possible role in the resurgence of malaria in Djibouti, Horn of Africa. Acta Trop. 2014;139:39-43.

4. Carter TE, Yared S, Gebresilassie A, Bonnell V, Damodaran L, Lopez K, et al. First detection of Anopheles stephensi Liston, 1901 (Diptera: culicidae) in Ethiopia using molecular and morphological approaches. Acta Trop. 2018;188:180-6.

5. WHO. Vector alert: Anopheles stephensi invasion and spread. 2019. https:// www.who.int/news-room/detail/26-08-2019-vector-alert-anophelesstephensi-invasion-and-spread. Accessed 31 May 2020.

6. WHO TWHO. World malaria report 2020. WHO. 2020. https://cms.who.int/ publications-detail-redirect/9789240015791. Accessed 16 May 2021.

7. Coetzee M. Key to the females of Afrotropical Anopheles mosquitoes (Diptera: Culicidae). Malar J. 2020;19:70.

8. Ageep TB, Damiens D, Alsharif B, Ahmed A, Salih EH, Ahmed FT, et al. Participation of irradiated Anopheles arabiensis males in swarms following field release in Sudan. Malar J. 2014;13:484.

9. Kumar NP, Rajavel AR, Natarajan R, Jambulingam P. DNA barcodes can distinguish species of Indian mosquitoes (Diptera: Culicidae). J Med Entomol. 2007:44:01-7.

10. Folmer O, Black M, Hoeh W, Lutz R, Vrijenhoek R. DNA primers for amplification of mitochondrial cytochrome c oxidase subunit I from diverse metazoan invertebrates. Mol Mar Biol Biotechnol. 1994;3:294-9.

11. Takken W, Lindsay S. Increased threat of urban malaria from Anopheles stephensi mosquitoes, Africa. Emerg Infect Dis. 2019;25:1431-3.

12. de Santi VP, Khaireh BA, Chiniard T, Pradines B, Taudon N, Larréché S, et al. Role of Anopheles stephensi mosquitoes in malaria outbreak, Djibouti, 2019. Emerg Infect Dis. 2021;27:1697-700.

13. Mohamed NS, Ali Y, Muneer MS, Siddig EE, Sibley CH, Ahmed A. Malaria epidemic in humanitarian crisis settings the case of South Kordofan state, Sudan. J Infect Dev Ctries. 2021;15:168-71.

14. Chaccour C, Killeen GF. Mind the gap: residual malaria transmission, veterinary endectocides and livestock as targets for malaria vector control. Malar J. 2016;15:24.

15. Sterkel M, Haines LR, Casas-Sánchez A, Adung'a VO, Vionette-Amaral RJ, Quek $S$, et al. Repurposing the orphan drug nitisinone to control the transmission of African trypanosomiasis. PLoS Biol. 2021;19:e3000796. 
16. Surendran SN, Sivabalakrishnan K, Sivasingham A, Jayadas TTP, Karvannan $K$, Santhirasegaram S, et al. Anthropogenic factors driving recent range expansion of the malaria vector Anopheles stephensi. Front Public Health. 2019;7:53. https://doi.org/10.3389/fpubh.2019.00053.

17. Seyfarth M, Khaireh BA, Abdi AA, Bouh SM, Faulde MK. Five years following first detection of Anopheles stephensi (Diptera: Culicidae) in Djibouti, Horn of Africa: populations established-malaria emerging. Parasitol Res. 2019;118:725-32

\section{Publisher's Note}

Springer Nature remains neutral with regard to jurisdictional claims in published maps and institutional affiliations.
Ready to submit your research? Choose BMC and benefit from:

- fast, convenient online submission

- thorough peer review by experienced researchers in your field

- rapid publication on acceptance

- support for research data, including large and complex data types

- gold Open Access which fosters wider collaboration and increased citations

- maximum visibility for your research: over $100 \mathrm{M}$ website views per year

At BMC, research is always in progress.

Learn more biomedcentral.com/submissions 